Communication and Marketing of Services by Religious

Organizations in India

Sriya Iyer, Chander Velu and Adbul Mumit

January 2010

CWPE 1008 


\title{
Communication and Marketing of Services by Religious Organizations in India ${ }^{1}$
}

\author{
Sriya Iyer ${ }^{2}$
}

Chander Velu ${ }^{3}$

Abdul Mumit ${ }^{4}$

${ }^{1}$ This work has been funded by the Spiritual Capital Research Program, sponsored by the Metanexus Institute on
Religion and Science, with the generous support of the John Templeton Foundation. We are also grateful for a
research grant from the Isaac Newton Trust, University of Cambridge. We are especially indebted in India to
Indicus Analytics who helped collect the data for the religion survey. We also thank the Editors and the referees for
their very helpful comments.
${ }^{2}$ Corresponding author: Faculty of Economics and St. Catharine's College, University of Cambridge, Sidgwick
Avenue, Cambridge CB3 9DD, United Kingdom. Tel: 441223335257 . Email: Sriya.lyer@econ.cam.ac.uk
${ }^{3}$ Judge Business School, University of Cambridge. c.velu@jbs.cam.ac.uk
${ }^{4}$ Faculty of Economics, University of Cambridge. ma464@cam.ac.uk 


\begin{abstract}
Marketing communication is a vital strategic tool for religious organizations to achieve competitive differentiation. The determinants of religious organizations' use of direct and indirect communication channels offers valuable insights into their modus operandi. This paper uses novel primary survey data on 568 Hindu, Muslim, Christian, Sikh and Jain organizations spread over 7 major states in India that we collected over the period 2006-2008, to investigate the determinants of communication channel selection by religious organizations. The findings suggest that state-specific effects for Karnataka, Maharashtra, Uttar Pradesh and West Bengal; and religion-specific fixed effects for Muslims play a predominant and persistent role in communication channel selection decisions. Religious organizations adopt direct channels more extensively to communicate changes to non-religious service provision. In a competitive framework, religious organizations also use indirect channels more extensively in response to information received about competitors. Additionally, intensive market competition leads religious organizations to increase their use of direct channels in response to information received about competitors through direct channels. Collectively, the findings suggest that across all religions in India, marketing communication plays a very important role for religious organizations in order for them to differentiate themselves from other competitors.
\end{abstract}

Keywords: Religious marketing, marketing communication, competition, religious organizations, India. 


\section{Introduction}

In recent times, organizations increasingly consider marketing communication as a strategic marketing tool, rather than as a tactical procedure for optimizing the marketing mix. The establishment, maintenance and enhancement of a distinctive and positive brand identity are achieved not only through the consumer's interaction with the product or service, but also through the long-run effects of communication. Furthermore, the customer's view of the marketer's brand is formed not only by the kinds of messages exchanged, but also by the choice of media (Schultz and Kitchen, 2000). The effect of the choice of communication channels has strategic implications for both for-profit and not-for-profit organizations such as religious organizations.

The existing literature on religious organizations suggests that many are providing valuable services both in terms of religious and non-religious services and that in many countries, these activities often substitute for the lack of state provision, as well as being consonant with the principles that underlie many religious traditions (Berman, Iannaccone and Ragusa, 2007). However some research from economics and related disciplines has also shown that in a competitive environment, analogous to firms retaining customers, religious organizations retain and attract adherents by using marketing tools to ensure customer satisfaction (Shawchuck et al, 1992). Recent studies emphasize the importance of marketing communication as an integral tool of the marketing process, which religious organizations employ to create a differentiated brand positioning (Abreu, 2006). In this sense, a religious organization can be viewed in much the same way as other firms in a market. For that reason, the selection of the appropriate communication channels with which to communicate its message may be an essential determinant of a religious organization's ability to persist and succeed.

The current literature in marketing has not laid sufficient emphasis on the communication strategy of religious organizations. Especially, empirical research pertaining to the communication strategy of religious organizations is limited. In this context, the current research makes a contribution to the extant literature by studying the determinants of a religious organization's communication strategy in a specific empirical setting, drawn from a developing country - India - that is characterized both by the multiplicity of religions and religious organizations. We present unique primary survey data that we have collected on 568 Hindu, Muslim, Christian, Sikh and Jain organizations in 7 Indian states over the period 2006-2008, to investigate the determinants of communication channel selection by religious organizations. Media richness theory is used to formulate a theoretical foundation for the direction of causality from competitive, message and service provision characteristics to the religious organization's channel selection decision i.e. between direct and indirect channels of communication.

Our results indicate that regional and religion-specific fixed effects play a predominant and persistent role in communication channel selection. For instance, the regional effects of Karnataka, Maharashtra, Uttar Pradesh and West Bengal are statistically significant for both direct and indirect communication channels. Additionally, we find that Muslim organizations are more reliant on direct communication channels compared to organizations of other religions. We also find that religious organizations adopt direct channels more extensively to communicate non-religious service changes; and that in the presence of competition, religious organizations also use indirect channels more extensively in response to information received about competitors. Our findings suggest that the use of direct and indirect communication channels by 
religious organizations is important and that these might vary both across religion and across region in the sub-continent, and elsewhere.

\section{Marketing and Communication of Religion}

The study of marketing in the context of religious organizations is an important area of research (Abreu, 2006). In this section we review the existing literature on the marketing of religious organizations; and the determinants of communication channel selection.

\section{Marketing of Religious Organizations}

We locate our study of religion, communication and marketing in India in the context of broader research on religious organizations both in developed and developing countries (Iannaccone, 2005; Iyer, 2008). Studies on religious organizations that are motivated from economics and the management literature have focussed on faith-based welfare programmes, the economic regulation of the church and the influence of religion on economic behaviour (Berman and Iannaccone, 2008). Adam Smith first made reference to the church in The Wealth of Nations, and Max Weber discussed the influence of the Protestant ethic on capitalism (Weber, 1904). Studies of the economics of religion have focused both on supply-side and demand-side issues (Azzi and Ehrenberg 1975; Stark, Iannaccone and Finke, 1996; Iannaccone, Finke and Stark, 1997; Stark and Finke, 2000; Lechner, 2006). These studies have examined both the structure of religious organizations and consumer preferences for religious services. In this context, the supply of religion is provided by religious organizations behaving similarly to firms in a competitive market by providing a range of services to attract potential customers. In this context, buyers (the individuals) and sellers (or the religious organizations) meet in a marketplace in which supply and demand dictate allocations of adherents across religions (Lechner, 2006). Other research more widely in the economics of religious organizations explores the relationship between regional issues and religion (Iannaccone and Makowsky, 2007); economic perspectives on terrorism (Berman and Laitin, 2004; Sandler and Enders, 2004; de Mesquita, 2005; Krueger, 2007); and specifically with respect to communication, the effect of media and education on the attitude of the Muslim world towards the US (Gentzkow and Shapiro, 2004). Other macroeconomic studies examine the structure of markets to explore how state religions interact with the freedom of markets and economic growth (La Porta et al., 1999; Stark and Finke, 2000; Barro and McCleary, 2003; Guiso, Sapienza and Zingales, 2003; Barro and McCleary, 2005; Gruber and Hungerman, 2006).

In the context of this broader literature it is worth emphasizing that in addition to the important social services that religious organizations unquestionably provide one aspect that is worth examining more closely is the market orientation of such organizations, or to what extent these organizations are cognizant of, or use market intelligence to their advantage. Market orientation involves how organizations gather, disseminate and respond to intelligence (Kohli and Jaworski, 1990). Research has shown that increased market orientation improves performance (Han and Srivastava, 1998; Atuahene-Gima, 1995). We acknowledge that the realities of many local area churches or mosques consist of trying to maintain infrastructure, providing for priests' salaries, 
supporting missionaries, and so forth. And for these organizations, the notion of market orientation might seem far removed from the realities of maintaining their current activities. But we argue that for other religious organizations, market orientation might matter more.

The market orientation of organizations in the nonprofit sector has been significantly emphasized in recent literature (Sargeant, Foreman and Liao, 2002; Padanyi and Gainer, 2004; White and Simas, 2008; Hsieh, Curtis and Smith, 2008) Nonprofit organizations are increasingly embracing marketing strategies and tactics to successfully encounter greater accountability in the handling of donated funds and cutbacks in public support (Gainer and Padanyi, 2005). However, the nature of the marketing orientation of non-profit organizations is distinct from their for-profit counterparts (Kara et al., 2004). The difference essentially arises from the lower emphasis placed on the maximization of financial rewards and the nature of the relationship with multiple stakeholders (donors, community, and target audience) that the non-profit organization must serve. Empirical analyses indicate that the implementation of marketing orientation provides direct benefits to non-profit organizations (Hsieh, Curtis and Smith, 2008; Gainer and Padanyi, 2005; Kara, Spillan and DeSheilds, 2004). A comprehensive meta-analysis of the links between marketing orientation and organizational performance demonstrates a strong relationship in the non-profit context (Shoham et al., 2006). Research has shown that the relationship between market orientation and performance also applies to religious organizations. In the specific context of religious organizations, market orientation is found to be positively correlated with improved overall church performance (White and Simas, 2008). Furthermore, creation of brand awareness through effective communication of brand personality has a significantly positive impact on the intention of donors to give (Hou, Du and Tian, 2009). Being market orientated enables religious organizations to respond to market intelligence with new service offerings. Such a response requires religious organizations to be able to communicate their new service offerings effectively. Therefore, studying how religious organizations communicate, and their implications for social marketing and branding, are important considerations for performance.

Previous studies consider social marketing as a basis for religious marketing and analyze the branding strategy of a religious organization from the perspective of market positioning and brand identity (Abreu, 2006). Social marketers simultaneously aim to satisfy the individual consumers' needs and maximize long-run social welfare while being constrained by monetary and institutional resources (Miller, 2002). Religious organizations initiate their marketing strategy by deciding on brand positioning i.e. by creating a unique brand identity in the mental map of the consumer in reference to other similar religious organizations. Consequently, they develop and execute a communication strategy that establishes their brand identity. Previous studies in the marketing of the church analyze how church services satisfy the needs of attendees (Moncrief, Lamb and Hart, 1986, Mehta and Mehta, 1995). In this context, how churches communicate with adherents is important. In analyzing the communication techniques used by churches, adherent growth was observed to be positively correlated with broadcasting of church services in direct media channels such as event sponsorships; and in indirect media channels such as TV, radio, newspaper and yellow pages (McDaniel, 1989; Vokurka and McDaniel, 2004). In a study pertaining to southern Baptist convention churches, direct communication methods via in-house visits and telephone calls tend to have higher perceived effectiveness than indirect channels, and marketing communication is considered the single-most significant contributor to church growth (Vokurka, McDaniel and Cooper, 2002). 
The effect of marketing communication on new product adoption has been extensively researched (Rogers, 1983; Gatignon and Robertson, 1991; Steenkamp and Gielens, 2003; Meuter et al., 2005). In analyzing the effect of various communication channels on adoption behavior, research suggests that direct channels have substantially stronger impact on adoption timing in comparison to mass media channels (Prins and Verhoef, 2007). This finding is attributed to the functional characteristics of indirect communication channels, whereby mass communication is only useful for generating awareness and disseminating information. Behavioral changes require further persuasion and hence necessitate the use of more personal and direct communication schemes. However, adoption and diffusion is also affected by competitive marketing communication. On the one hand, competitors' communication can aid in creating and expanding the market by increasing the market penetration rate (Mahajan, Sharma and Buzzell, 1993, Krishnan, Bass and Kumar, 2000). On the other hand, experimental studies demonstrate that the memorability of an advertised item reduces with greater exposure to advertisements for competing products (Keller, 1987). Furthermore, the adoption probability is significantly reduced by a greater degree of competitive advertising (Steenkamp and Gielens, 2003). The next section discusses the determinants of marketing communication channel selection.

\section{Determinants of Communication Channel Selection}

Marketing communication channels can be broadly categorized as personal channels which involves persons communicating directly; and non-personal channels which involves indirect interaction (Kotler, 2002). Direct or personal channels include face-to-face conversations, video conferencing, and email communication among persons. The opportunity for individualizing the message and gathering immediate feedback establishes the effectiveness of these channels. Indirect or impersonal channels include the traditional broadcast and print media, outdoor display advertisements and marketing events. Apart from the direct influence of the mass media on receivers, inter-personal communication also plays a critical part in affecting personal attitudes and behavior (Katz, 1973). The two-step theory of communication, which is widely supported empirically, suggests that influences emanating from the mass media primarily reach the 'opinion leaders' who consequently interact with other members of their social group and disseminate information through their influential role within the group (Katz and Lazarsfeld, 1955; Weimann and Brosius, 1994; Weimann et al., 2007). Furthermore, interpersonal associations with opinion leaders pressurize members to conform to the group's norms and values, and function as sources of social support (Katz, 1973).

The selection of alternative channels of communication significantly also relies on channel attributes. The degree of congruence between channel attributes and the social and psychological needs of the receiver determines the selection of the sender's communication channel (Katz, Gurevitch and Haas, 1973). This 'uses and gratifications' approach entails that institutional factors (politics, education, religion and family) and psychological factors (self-identity, selfgrowth and self-gratification) create a distinct set of needs for the receiver. The attributes of various communication channels offer opportunities for gratification of these needs, and therefore the receiver actively optimizes between the channels to maximize their needs and satisfaction. 
The 'media richness' theory examines channel selection from the sender's perspective. The message carrying capacity of a communication channel, termed as media richness, determines the effectiveness of communication (Daft, Lengel and Trevino, 1987). The richness of the channel is determined by its ability first transmit feedback; secondly to transmit multiple cues such as body language, speech intonations and so forth; thirdly, to customize the message for the receiver; and finally, to convey emotions (Daft and Lengel, 1984). The degree of media richness necessary for communication increases with the degree of uncertainty and complexity of the message. Previous studies have ranked various communication channels in accordance with these criteria to designate direct face-to-face communication as the richest media channel (Newberry, 2001). Indirect asynchronous channels are categorized as the leanest, and thus ineffective for transmission of complex and persuasive messages. A higher degree of equivocality and complexity of the message makes the use of richer media imperative. However, uncomplicated messages afford senders the freedom to exercise individual preferences. Furthermore, individual cognitive characteristics of the sender can dominate the need for media richness (Trevino et al., 1990).

The competitive dimension in channel selection is also noteworthy. Brand positioning requires an organization to define its identity and simultaneously to differentiate itself from competitors (Aaker, 1991). As communication channels, along with the message, are used to form a brand identity, the differentiation constituent entails that channel selection is responsive to competition strategies.

Media selection studies in marketing utilize both qualitative and quantitative models (simulation, heuristic, or multi criteria decision-making) in terms of budget allocation and target audience characteristics (Kwak, Lee and Kim, 2005). In general terms, from the marketing perspective, media selection can be viewed as an optimization problem that maximizes outcome measures such as rating points, media exposure and so forth, given certain resource constraints such as the budget, or the number of employees, by assigning optimal weights to various communication media. Pasadeos et al (1997) indicate that media planning can be theoretically approached along two mutually interactive dimensions, namely the media approach which is the physical and psychological characteristics of various mediums; and the consumer and audience approach which relates to target audience characteristics. Target audience traits such as demographic and psychographic traits often play a pivotal role in the media selection process (Abratt and Cowan, 1999; Assael and Poltrack, 1999; Kazuya, 2002). For instance, Assael and Poltrack (1999) demonstrate that product ownership and user characteristics are useful criterion for media selection. Parallel to the channel attribute aspect of communication channel selection, the influence of media characteristics on media selection optimization has also been empirically demonstrated (Zufryden, 2000; Berkowitz, Allaway, D’Souza, 2001; Cannon et al., 2002).

\section{Research Hypotheses}

This theoretical literature allows us to develop four testable hypotheses. According to the media richness theory, in communicating new services that require greater persuasion or induce behavioral transformations, organizations tend to utilize richer media channels. In the current context, the aggregate service offering of a religious organization is separated into the exclusive and exhaustive categories of religious and non-religious services. Religious services include the propagation and expansion of faith, religious education, and the performance of religious rituals 
such as weddings. Non-religious services include education, health, employment, child care, and food distribution. Change in religious services describes a change in the degree of tradition compared to 20 years back, and changes to non-religious service provision are changes in the number of non-religious service offerings from 1990-2006. Therefore, a new religious service offering that constitutes a change in the degree of tradition may need greater elucidation by the religious organization and thus imply a greater dependence on richer media channels. However, if the change in religious services is being driven by the market, perhaps emanating from more general socio-cultural shifts, then followers do not need to be educated about the change. However, direct communication channels substantially impact adoption timing in comparison to indirect channels (Prince and Verhoef, 2007). From a competitive perspective, religious organizations use richer media channels for communicating service changes that highlight their key points-of-difference. As opportunities for changes to core religious services are limited, nonreligious service changes are the key differentiating characteristic between religious organizations. Consequently, it is optimal for religious organizations to use direct communication channels for communicating non-religious service changes. Therefore we suggest the following hypothesis:

HYPOTHESIS 1. Religious organizations use direct channels more extensively to communicate changes to non-religious service provision.

Media richness theory predicts that, as religious messages are usually more complex, require feedback and multiple cues - religious organizations would tend to use richer media channels or direct communication channels for communicating religious services. Therefore, one prediction may result from the dominance of message characteristics over competitive aspects. However, the predictions of media richness theory itself are contentious. For instance, individual heterogeneity may dominate over message characteristics (Trevino et al., 1990) or media richness may not remain constant but vary across social settings (Newberry, 2001). Under these circumstances, media richness theory's prediction of the religious organizations' use of direct channels for communicating religious services would not obtain. Therefore, the utilization of direct channels for communicating non-religious services may result either from the invalidity of media richness theory, or from the dominance of competitive factors over message characteristics.

In contrast, according to the 'brand positioning' model, organizations identify and communicate points-of-difference to create a distinctive brand (Keller, Sternthal and Tybout, 2002). Points-ofdifference need to be desirable to consumers, deliverable by the brand and can differentiate from competitors. Accordingly, religious organizations will tend to use richer media channels for communicating their points-of-difference in terms of religious and non-religious services. Moreover, as change in religious services is often constrained due to traditions and legal customs, non-religious services provide a significant opportunity to achieve differentiation from competitors. Consequently, as richer media offers a greater opportunity for emphasizing pointsof-difference, religious organizations would generally tend to use direct channels for communicating non-religious services. 
HYPOTHESIS 2. Religious organizations use direct channels more extensively in order to communicate non-religious services.

The creation and maintenance of brand identity requires the organization to differentiate itself from the competition (Aaker, 1991). Achieving differentiation through communication channels allows religious organizations to establish a unique brand identity. Religious organizations differentiate themselves by selecting alternative channels in relation to competitors. For instance, greater use of indirect channels by competitors would make it preferable for the incumbent to focus more on direct channels.

However, the reaction of the incumbent religious organization towards competitors would be dissimilar for indirect and direct communication channels. The theory of social ties suggests that social agents react differently towards information received from strong and weak ties (Granovetter, 1973). Therefore, as the incumbent religious organization increasingly receives information about its competitors through the weak ties of indirect channels, it might react by increasing its own use of indirect channels in an effort to 'match' their competitors.

HYPOTHESIS 3. Religious organizations use indirect channels more extensively in response to an increase in information received about competitors through indirect channels.

In the context of our research, competition is measured by other religious organizations in the geographical vicinity of the incumbent. The degree of competition in the market, which is signified by the number of larger competitors, the degree of competitiveness, and the degree of responsiveness towards religious and non-religious services, would influence the incumbent religious organization's reaction towards information received about competitors through direct and indirect channels. For instance, the market power of the incumbent religious organization affects the degree of competitive response. A higher degree of competition in the market garners a stronger competitive response from the incumbent religious organization as it attempts to achieve differentiation. On the contrary, a religious organization that operates in a relatively less competitive setting would have lesser incentive to differentiate itself.

HYPOTHESIS 4. Increasing market competition will amplify the reaction (utilization of direct and indirect channels) of religious organizations towards information received about competitors through direct and indirect channels.

In summary, Hypotheses 1 and 2 primarily relate to the effect of the number of, and changes to non-religious service provision, on the use of direct communication channels. Hypotheses 3 and 4 are based on the mediating effect of competition on the use of direct and indirect channels by religious organizations.

\section{The Survey of Religious Organizations in India}

In order to test these four hypotheses, we use unique survey data on religious organizations in India. This section briefly outlines the survey of religious organizations conducted in India from 2006-2008. As far as we are aware, this is one of the first large-scale Indian surveys of 568 religious organizations with a view to understanding their economic, marketing and competitive behavior. It involved extensive primary data collection and careful fieldwork using a 
combination of questionnaire, participant observation, and personal interview methods. In consequence, the survey was an extremely challenging task of coordination and execution, requiring over 50 surveyors working over 328 man-days in 7 major Indian states over two years. More detailed information about the survey design and the data collected is presented below.

Table 1 here

The survey consisted of interviews with 272 Hindu (47.89\%), 248 Muslim (43.66\%), 25 Christian (4.40\%), 23 Sikh and Jain organizations (4.05\%) based in the Indian states of Jammu and Kashmir, Uttar Pradesh, West Bengal, Madhya Pradesh, Gujarat, Maharashtra and Karnataka, as shown in Table 1. First, a random sample of religious organizations in selected districts of each state was done, based on a listing of all religious organizations provided by the Registrar of Charities for each state in India that we considered.

The questionnaire survey that was administered to the organizations consisted of a series of questions that were grouped into five mains sections: demographics which covered basic information about the organizations, background changes that included perceptions about changes in inequality, change in religious and non-religious service provision, knowledge of other organizations, and questions on donations received and expenditure incurred. Within these broad categories, the survey included specific questions on basic demographics; areas of operation; adherent numbers; religious practices and religious service provision; non-religious service provision; perceptions of how all types of service provision have changed over time and especially post the economic liberalization of the early 1990s; sources of income and expenditure including donations and other assets; and perceptions of competitive intensity with other religious organizations (see Iyer et al., 2009 for a more detailed description). The survey included a series of questions about organizations' communication and marketing strategies which is the focus of this particular paper.

We emphasize particularly that this survey was an extremely challenging task of coordination and execution as shown in Table 2 which illustrates the main districts of India covered by the research.

Table 2 here

In terms of the logistics of conducting the survey, the key column of interest is the one that shows the average number of visits per interview. This varies between 1.6 visits to 3.5 visits per religious organization as the researchers usually interviewed a maximum of 3 people in each organization to obtain the information needed. These three people typically included a temple trustee or priest, an accounts officer, and an administrative officer who runs the organization.

Among the religious services provided by the organizations, propagation of the faith (30.63\%) and religious education (32.75\%) are considered to be the two most important activities. Also, the motivation for the service offering of religious organizations included 'it was a virtuous thing to do' $(83.80 \%)$, 'others did not provide these services' $(16.02 \%)$, 'in response to provision by other organizations' (33.10\%), and 'a requirement for the area' (41.20\%). Additionally, compared to 20 years previously, 238 organizations (41.9\%) reported that religious services overall are more traditional, compared to 209 organizations (36.8\%) who said they are less traditional, while 112 organizations (19.72\%) felt they had stayed the same. Furthermore, nearly 
all religious organizations increased their provision of every non-religious service. The most popular non-religious services provided are education, health-care and food distribution, closely followed by child care, and then distantly by employment and other services. This pattern has remained unchanged before and after 1991, a watershed year for the Indian economy as it marked the beginning of substantial trade liberalisation, deregulation and economic growth for the country. Religious organizations also viewed the provision of non-religious services as a key way in which to propagate and to expand their faith - over 55\% of organizations thought this was very important in the post-1991 period, and this increased substantially relative to the pre-1991 period. Most religious organizations considered the creation of goodwill and increase in religious adherents as the main gain from providing religious and non-religious services. In relation to the number and size of other organizations operating in the same area, 150 organizations reported 12 others; 136 reported 3-5 competitors; 96 reported 6-10; and 74 reported over 10 organizations as competitors (112 reported that they did not know their competition).

Tables 3 and 4 illustrate the channels of communication used by the religious organizations and the channels through which they receive information about their competitors.

Table 3 here

Table 4 here

Tables 3 and 4 suggest that newspapers, panchayat (local self-government institutions) meetings and word of mouth are the most significant vehicles of propagation of communication about the organizations' services. Television and radio is used less frequently. The channels of communication for their own services do not vary greatly by religious organizations. Newspapers and word of mouth seem to be the most effective communication channels for Hindus and Muslims. Christian organizations are more reliant on newspapers and other media for their information about other organizations, probably a reflection of the higher literacy levels in the Christian community more generally in India. Other organizations use panchayat meetings and word of mouth channels more than the Hindus, Muslims and Christians.

\section{Methodology and Econometric Model}

In order to test the hypotheses econometrically, we use the following variables: the dependent variables are the number of direct channels (local panchayat meetings, word of mouth, and others) and the number of indirect channels (television/radio, newspapers/other print media) used by the incumbent religious organization. Our explanatory variables include competition, change and message characteristics variables. We include fixed effects to account for region-specific and religion-specific heterogeneity. Organizational variables are also included as control variables for individual heterogeneity. We summarize the control and explanatory variables in Table 5.

Table 5 here

The media selection problem may be stated in the form of an optimization problem whereby given a set of media options, communications budget, and various data about the media and the audience to be reached, the firm optimally selects options to maximize profit or some related 
measure of performance (Little and Lodish, 1969). In this study we examine the number of channels used as an optimization outcome for achieving certain organizational objectives ${ }^{5}$.

Consequently, we estimate two separate regressions of the following form:

$Y_{k i}=\beta_{0}+\beta_{1}$ RELIGION $+\beta_{2}$ REGION $+\beta_{3}$ ORGANIZATIONAL $+\beta_{4}$ COMPETITION + $\beta_{5} M E S S A G E+\beta_{6} S V C . I N N O V+e_{i} \ldots$

In which $Y_{1 i}=$ Number of direct channels used by the $i$-th organization, and $Y_{2 i}=$ Number of indirect channels used by the $i$-th organization.

\section{Results and Discussion}

We examine first the distributional characteristics of the use of direct and indirect communication channels by the incumbent religious organization.

Table 6 here

The direct channels of communication include word-of-mouth, local panchayat meetings and other forms of direct communication. We observe that nearly all of the religious organizations (97.9 \%) use at least one direct communication channel. The majority of the organizations employ two direct communication channels.

Table 7 here

The indirect channels of communication include electronic media such as television and print media such as newspapers. Interestingly, we note that the proportion of religious organizations that do not use any communication medium is relatively greater for indirect channels in comparison to direct channels. This may have resulted from the relative costliness of indirect channels as organizations incur greater costs for communicating services. The majority of the organizations use one indirect communication channel.

The discrete nature of the dependent variable suggests that it is appropriate to use count data regression modeling. The Poisson and Negative Binomial are the basic models for count data estimation and form the basis of more sophisticated procedures such as the zero-inflated Poisson

\footnotetext{
${ }^{5}$ Optimal media options are defined as $\tau^{*}$, where $\tau=$ number of advertising insertions (Zufryden, 1973; Kwak et al., 2005). Empirically, organizations assign specific proportions of their budget to various media channels i.e. with exogenous constant cost per insertion $c$, the media weight in monetary terms allocated to the $i$-th channel is $=\frac{\sum_{i=1}^{n} C_{i} \tau_{i}}{\sum_{i=1}^{n} \sum_{j=1}^{k} C_{i j} \tau_{i j}}$ (Channels $=1 \ldots k$, Insertions $=1 \ldots n)$. In our research, we essentially re-posit the optimization problem such that firms optimally select the number of channels with corresponding media weight $=\frac{\mathrm{C}_{\mathrm{j}}}{\sum_{\mathrm{j}=1}^{\mathrm{k}} \mathrm{C}_{\mathrm{j}}}$.
} 
and Negative Binomial models. To select between Poisson and Negative Binomial models, we use the likelihood ratio test to examine the null hypothesis of equidispersion $(\alpha=0)$. The likelihood statistic is calculated as $\mathrm{LR}=2\left\{\ln L_{\text {Negative binomial }}-\ln L_{\text {Poisson }}\right\} \sim x^{2}(1)$, which is chi-squared distributed with one degree of freedom. There is no evidence of overdispersion, as the null hypothesis of $\alpha=0$ cannot be rejected at $1 \%$ level of significance for any of the specifications. Therefore, as $\alpha=0$, the Negative Binomial model is reduced to the Poisson regression model. Consequently, we estimate the Poisson regression model for all specifications. Tables 8 and 9 present the main results from the Poisson regressions estimated.

Table 8 here

Table 9 here

In presenting our results, we report the percentage change in the expected count that arises from $\delta$ units change in $x_{k}$, holding all other variables constant. The percentage change in the expected count due to $\delta$ units change in $x_{k}$ (holding other variables constant) is given by: $\frac{E\left[y \mid X, x_{k}+\delta\right)-E\left[y \mid X, x_{k}\right)}{E\left[y \mid X, x_{k}\right)} * 100=100 *\left[e^{\beta_{k} \delta}-1\right]$. This can be interpreted as a change in $x_{k}$ by $\delta$ units leads to a $100 *\left[e^{\beta_{k} \delta}-1\right]$ percent change in the expected count. The standard errors are estimated through the bootstrap method, which requires weaker stochastic assumptions, and has better small-sample performance (Cameron and Trivedi, 1998).

The regional effects of Karnataka, Maharashtra, Uttar Pradesh and West Bengal are statistically significant for both direct and indirect communication channels. The regional effects for indirect channels are strongly positive. When a religious organization is located in Karnataka, Maharashtra, Uttar Pradesh, Gujarat or West Bengal, it uses on average 50\% more indirect channels in comparison to the base state Madhya Pradesh. Conversely, except Maharashtra, location in Karnataka, Uttar Pradesh or West Bengal reduces the expected use of direct communication channels by $20 \%$ on average.

A Muslim religious organization uses $11.5 \%$ more direct communication channels than a baseline Hindu religious organization. One reason for this may be the Islamic tradition of religious circles that are arranged in mosques to disseminate religious knowledge and the weekly congregational 'Jummah' prayer on Fridays. These congregations afford suitable opportunities to use direct communication channels for propagation of information relating to religious and nonreligious services.

None of the organizational variables, which are control variables, appear to have any significant effect on direct or indirect channel selection. The statistical insignificance is robust to alternate formulations of the variable in logarithmic terms. A Wald test to estimate the joint significance of the variables does not allow us to reject the null hypothesis

$\left\{H_{o}: \beta_{\text {Adherents }}=\beta_{\text {Gatherings }}=\beta_{\text {Operation }}=\beta_{\text {Location }}=0\right\}$ at $10 \%$ level of significance. Therefore, we conclude that organizational factors, as measured by our variables, do not have any statistically significant effect on channel selection. 
Hypothesis 1 posits that religious organizations use direct channels more extensively in order to communicate non-religious service changes, and the findings support the null hypothesis. The change-in-service provision variables have statistically significant effects on direct communication channels only. Changes in non-religious services are primarily communicated through direct communication channels, whereby change in a non-religious service leads to an increase of $6.6 \%$ in direct communication channel utilization, as shown in Table 9. These results imply that religious organizations tend to use richer media channels for communicating about non-religious service changes. This particular result indicates that religious organizations adopt non-religious service changes as their key point-of-difference with competitors. As religious services are primarily defined by religious theology located in religious scriptures, differentiation opportunities with respect to religious services are limited by construction. Therefore, religious organizations focus more on non-religious services as their key differentiator and consequently use richer media channels to emphasize their unique propositions. The interaction terms between service changes and competitive advantage (not reported here) are not significant for either direct or indirect communication channels.

Hypothesis 2 argues that religious organizations will use direct channels more extensively in order to communicate non-religious service offerings. We note that the parameter estimates for both number of religious and non-religious services provided by the incumbent religious organization are insignificant (not reported here). This particular finding may arise from the fact that the message characteristics (whereby direct channels are used for communicating religious services) and competitive factors (whereby direct channels are used for communicating pointsof-difference non-religious services) negate each other, and hence neither effect predominates.

Initially in our estimations we include the number of direct and indirect communication channels through which the incumbent religious organization receives information about its competitors. Perceptibly, the channel employed by the sender may not correspond to the receiver's channel of reception. For instance, the two-step flow of communication entails that information disseminated through mass media channels (television, radio, newspapers) may reach the final receiver through an intermediary. Thereby, the incumbent religious organization would reportedly reveal a positive bias towards its competitor's utilization of direct communication channels. Conversely, mass media coverage of particular direct communication strategies of competitors would cause the incumbent religious organization to report a positive bias towards its competitor's use of indirect communication channels. Therefore, there may be a dissonance between the channels through which the incumbent religious organization receives information about its competitors and the channels actually used by competitors.

Hypothesis 3 postulates that indirect channels are used more extensively in response to an increase in information received about competitors through indirect channels. The statistical effect of the number of indirect communication channels through which the incumbent religious organization receives information about its competitors on the number of indirect communication channels is significant. A unit increase in the competitor's number of indirect communication channels as reported by the incumbent religious organization leads to $19.3 \%$ increase in the number of indirect communication channels of the incumbent religious organization, as shown in Table 8. This suggests particularly that religious organizations react 
strongly when they receive information about a competitor's communication through indirect channels, supporting Hypothesis 3.

To explore this in further detail, we emphasize the theory of strong and weak ties (Granovetter, 1973), which focuses on the importance of interpersonal relationships for the diffusion of information and concludes that weak ties, which are connections through an intermediary, provide people with access to information and resources beyond those available in their own social circle. Correspondingly, agents exhibit differential responses towards information received from different ties. In the current context, a competitor's messages received through the strong ties of direct channels are not perceived to be significantly important and hence do not motivate a competitive response. Conversely, a competitor's messages received through the weak ties of indirect channels constitute 'big news' and elicit a different response.

Hypothesis 4 emphasizes that market competition augments the response of religious organizations use of direct and indirect channels towards information received about competitors through direct and indirect channels. In empirically assessing Hypothesis 4, we note that the interaction term between the number of direct channels used by competitors as reported by the focal religious organization and the number of larger firms in the vicinity has a statistically significant effect on the number of direct communication channels used by the focal religious organization. This means that the marginal effect of an increase in the competitor's number of direct communication channels on the focal organization's number of direct communication channels is increasing in the number of larger firms in the vicinity, by a factor of $1.5 \%$, as shown in Table 9. Therefore, the hypothesis is valid as increasing market competition amplifies the information received about competitors through direct channels only. Furthermore, interaction terms between the competitor's number of direct and indirect communication channels and the competitive advantage and degree of responsiveness for religious and non-religious services are not statistically significant. This indicates that the response of religious organizations towards communication strategies of competitors is not mediated by competitive advantage or responsiveness factors.

The interaction term between the number of non-religious services and degree of responsiveness towards non-religious services has a significant effect on both direct and indirect communication channel selection. In quantitative terms, this indicates that religious organizations, which are more responsive towards non-religious service provision by competitors, tend to decrease direct channel use by $4.5 \%$ (as shown in Table 9) and concurrently to increase the use of indirect communication channels by $4.7 \%$ (as shown in Table 8 ) for an additional non-religious service. In contrast, the parameter estimates of the number of religious and non-religious services (not reported here) do not have any significant effect on channel selection. Finally, in examining the goodness-of-fit statistics, we note that the Bayesian information criterion indicates that the most parsimonious model with only regional and religion fixed effects offers the best fit.

\section{Conclusion}

Marketing tools are increasingly being used by religious organizations in order to maintain and promote their market positioning by successfully retaining and generating adherents (Kotler and Andreasen, 1996). Marketing communication, being an integral element of the marketing mix, 
plays an essential role in the accomplishment of these objectives. The current research elucidates the underlying factors that affect the channel selection decisions of religious organizations. The findings show substantial and persistent regional and religion-specific fixed effects, along with competitive and service change effects.

In viewing the communication strategy of religious organizations through the theoretical lens of media richness theory and related concepts, we suggest that the incumbent organizations optimize their media strategy in a coordinated fashion. At the outset, this might seem an unrealistic expectation for small religious organizations who are serving underprivileged populations. However, although resource constraints vary widely across the spectrum, we think the channel optimization problem is essentially identical across religious organizations. Therefore, assuming homogenous levels of rationality of agents within religious organizations, we suggest that the same underlying model might depict the optimizing behavior of all religious organizations. Furthermore, a plethora of robust empirical evidence suggests that a significant proportion of religious organizations embrace the behavioural characteristics of market orientation regardless of their size, with marketing communication playing a major role in achieving organizational growth (McDaniel, 1989; Vokurka, McDaniel and Cooper, 2002; White and Simas, 2007; Hsieh, Curtis and Smith, 2008; Hou, Du and Tian, 2009).

However, we also acknowledge the disparate social and economic environments in which Indian compared to European or North American religious organizations operate. The current research concentrates more intensely on the objective and general determinants of channel selection. A possible extension would be to include subjective and situational factors. In our survey the dependent variable measures the variety of communication channels that a religious organization adopts. It is quite possible that given a stimulus for communication, a religious organization may opt to increase the intensity of its existing communication channels instead of increasing the number of channels. Additionally, the cost of media channels and the resource constraints typified by their communication budgets that religious organizations face, discernibly affect their channel selection strategy. These are possible areas for further extensions of our research. Furthermore, target audience traits constitute an important determinant of channel selection. Although the regional and religious fixed effects partially encompass the cross-sectional variations of the target audience, we are assuming the underlying homogeneity of these variables across cross-sectional observations in our analysis.

The current research also offers various opportunities for future research in the more general area of religion and marketing in developing countries like India. Availability of new data sets, especially over longer time periods, would provide a relevant context for testing the robustness of the findings under different socio-economic conditions. Collectively though, the research presented in this paper suggests that across all religions in India, and quite possibly in other developing countries as well, marketing communication may well be playing a very important and central role in the activities of religious organizations today. 


\section{References}

Aaker DA. 1991. Managing Brand Equity. The Free Press, New York.

Abratt R, Cowan D 1999. Client-Agency Perspectives of Information Needs for Media Planning. Journal of Advertising Research 39(6): 37.

Abreu M. 2006. The brand positioning and image of a religious organisation: an empirical analysis. International Journal of Nonprofit and Voluntary Sector Marketing 11: 139-146.

Assael H, Poltrack D.1999. Relating Products to TV Program Clusters. Journal of Advertising Research 39(2): 1-10.

Atuahene-Gima, Kwaku 1995. An Exploratory Analysis of the Impact of Market Orientation on New Product Performance, Journal of Product Innovation Management, 12(5), 275-293.

Azzi C, Ehrenberg RG. 1975. Household allocation of time and church attendance. Journal of Political Economy 83(1): 27-56.

Barro RJ, McCleary RM. 2003. Religion and economic growth across countries. American Sociological Review 68 (5): 760-781.

Barro RJ, McCleary RM. 2005. Which Countries Have State Religions? Quarterly Journal of Economics 120 (4): 1331-1370.

Berkowitz D, Allaway A, D’souza G. 2001. The Impact of Differential Lag Effects on the Allocation of Advertising Budgets across Media. Journal of Advertising Research 41(2): 27-36.

Berman E, Laitin D. 2004. Rational martyrs vs. hard targets: Evidence on the tactical use of suicide attacks. Paper presented at the Meetings of the Association for the Study of Religion, Economics and Culture, 22 October.

Berman E, Iannaccone, L. 2008. '"religion, economics of." The New Palgrave Dictionary of Economics. Second Edition. Eds. Steven N. Durlauf and Lawrence E. Blume. Palgrave Macmillan.

Berman E., Iannaccone, L. and Ragusa, G. 2007. From Empty Pews to Empty Cradles: Fertility Decline among European Catholics. Mimeograph, Department of Economics, University of San Diego.

Cameron AC, Trivedi PK. 1998. Regression Analysis of Count Data. Cambridge University Press.

Cannon H, Leckenby JD, Abernethy A. 2002. Beyond Effective Frequency: Evaluating Media Schedules Using Frequency Value Planning. Journal of Advertising Research: 33-47. 
Daft RL, Lengel RH. 1984. Information richness: a new approach to managerial behavior and organizational design. Research in organizational behavior 6: 191-233.

Daft RL, Lengel RH, Trevino LK. 1987. Message equivocality, media selection, and manager performance: Implications for information systems. MIS Quarterly 355-366.

de Mesquita EB. 2005. The Quality of Terror. American Journal of Political Science 49 (3): 515530 .

Gainer B, Padanyi P. 2005. The relationship between market-oriented activities and marketoriented culture: implications for the development of market orientation in nonprofit service organizations. Journal of Business Research 58(6): 854.

Gatignon H, Robertson TS .1991. Innovative decision processes. Handbook of Consumer Behavior. Prentice-Hall: 316-348.

Gentzkow M, Shapiro J. 2004. Media, education and anti-Americanism in the Muslim world. Journal of Economic Perspectives 18 (3): 117-133.

Granovetter M. 1973.The Strength of Weak Ties. American Journal of Sociology 78 (6): 13601380 .

Gruber J, Hungerman DM. 2006. The Church versus the Mall: What Happens When Religion Faces Increased Secular Competition?. Quarterly Journal of Economics 123 (2): 831-862.

Guiso L, Sapienza P, Zingales L. 2003. People's opium? Religion and economic attitudes. Journal of Monetary Economics 50(1): 225-82.

Han, J.K., N. Kim and R.K. Srivastava 1998. Market Orientation and Organizational Performance: Is Innovation the Missing link? Journal of Marketing, 62(October), 30-45.

Hanssen DM, Parsons LJ, Schultz RL. 2001. Market Response Models. 2nd edition. Kluwer Academic Publishers, Boston.

Hou J, Du L, Tian Z. 2009. The effects of nonprofit brand equity on individual giving intention: mediating by the self-concept of individual donor. International Journal of Nonprofit and Voluntary Sector Marketing 14 (3): 215-229.

Hsieh J, Curtis KP, Smith AW. 2008. Implications of stakeholder concept and market orientation in the US nonprofit arts context. International Review on Public and Nonprofit Marketing 5(1): $1-13$. 
Iannaccone LR, Finke R, Stark R. 1997. Deregulating religion: The economics of church and state. Economic Inquiry 35(2): 350-64.

Iannaccone LR. 2005. Looking Backward: A Cross-National Study of Religious Trends. Mimeo. George Mason University.

Iannaccone LR, Makowsky M. 2007. Accidental Atheists? Agent-Based Models of Mobility, Conformity, and Religious Regionalism. Journal for the Scientific Study of Religion 46(1): 1 16.

Iyer S. 2008. "religion and economic development." The New Palgrave Dictionary of Economics. Second Edition. Eds. Steven N. Durlauf and Lawrence E. Blume. Palgrave Macmillan.

Iyer S, Velu C, Xue J, Chakravarty T. 2009. Innovation and the resilience of religion. Mimeographed. Faculty of Economics, University of Cambridge.

Kara A, Spillan AE, DeShields OW. 2004. An empirical investigation of the link between market orientation and business performance in non-profit service providers. Journal of Marketing Theory and Practice 12 (2): 59-72.

Katz E, Lazarsfeld P. 1955. Personal Influence. The Free Press, New York.

Katz, E. 1973. The two-step flow of communication: an up-to-date report of an hypothesis. Marketing Classics. 175-193.

Katz E, Gurevitch M, Haas H. 1973. On the use of the mass media for important things. American Sociological Review 38:164-181.

Kazuya, K 2002. Affinity-based Media Selection: Magazine Selection for Brand Message Absorption. Journal of Advertising Research 42(4): 54-65.

Keller KL. 1987. Memory factors in advertising: The effect of advertising cues on brand evaluations. Journal of Consumer Research 14: 316-333.

Keller KL, Sternthal B, Tybout A. 2002. Three questions you need to ask about your brand. Harvard Business Review (September): 81-86.

Kohli, A and Jaworski B. 1990. Market Orientation: The Construct, Research Propositions, and Managerial Implications, Journal of Marketing, 54(2)1-18.

Kotler P, Andreasen AR. 1996. Strategic Marketing for Non Profit Organisations Management. Prentice Hall: New Jersey. 
Kotler P, Roberto EL. 1989. Social Marketing. The Free Press, New York.

Kotler P. 2002. Marketing Management. $11^{\text {th }}$ edition. Pearson Education, London.

Krishnan T, Bass F, Kumar V. 2000. Impact of a late entrant on the diffusion of a new product/service. Journal of Marketing Research 37: 269-278.

Krueger, AB. 2007. What Makes a Terrorist: Economics and the Roots of Terrorism. Princeton university press, New Jersey.

Kwak NK, Lee CW, and Kim JH. 2005. An MCDM model for media selection in the dual consumer/industrial market. European Journal of Operational Research 166: 255-265.

La Porta R, López-de-Silanes F, Shleifer A. 1999. The Quality of Government. Journal of Law, Economics and Organization 15 (1): 221-227.

Lechner FJ. 2006. SAGE Handbook of the Sociology of Religion. James A. Beckford and N.J. Demerath (eds).

Little JD, Lodish LM. 1969. A Media Planning Calculus. Operations Research 17 (1): 1-35.

Mahajan V, Sharma S, Buzzell R. 1993. Assessing the impact of competitive entry on market expansion and incumbent sales. Journal of Marketing 57: 39-52.

McDaniel SW. 1989. The Use of Marketing Techniques by Churches: A National Survey. Review of Religious Research. Special Issue: Methodological Issues in Congregational Studies .31 (2): 175-182.

Mehta SS, Mehta GB. 1995. Marketing of Churches: an Empirical Study of Important Attributes. Journal of Professional Service Marketing 13(1): 53-63.

Meuter M, Bitner M, Ostrom A, and Brown S. 2005. Choosing Among Alternative Service Delivery Modes: An Investigation of Customer Trial of Self-Service Technologies. Journal of Marketing 69: 61-83.

Miller KD. 2002. Competitive Strategies of religious organizations. Strategic Management Journal 23: 435-456

Moncrief WC, Lamb CW Jr, Hart SH. 1986. Marketing the church. Journal of Professional Services Marketing 4(summer): 55-63.

Newberry B. 2001. Raising Student Social Presence in Online Classes. WebNet 2001: World Conference on the WWW and Internet Proceedings, Orlando.

Padanyi P, Gainer B. 2004. Market orientation in the nonprofit sector: taking multiple constituencies into consideration. Journal of Marketing Theory and Practice 12(2): 43-58. 
Pasadeos Y, Barban A, Yi H, Kim BH. 1997. A 30-Year Assessment of the Media Planning Literature. Journal of Current Issues and Research in Advertising 19 (1): 23-36.

Prins R, Verhoef PC. 2007. Marketing Communication Drivers of Adoption Timing of a New EService among Existing Customers. Journal of Marketing 71 (2): 169-183.

Rogers EM. 1983. Diffusion of Innovations. The Free Press, New York.

Sandler T, Enders W. 2004. An economic perspective on transnational terrorism. European Journal of Political Economy 20 (2): 301-316.

Sargeant A, Foreman S, Liao M. 2002. Operationalizing the marketing concept in the nonprofit sector. Journal of Nonprofit and Public Sector Marketing 10(2): 41-64.

Schultz D, Kitchen P. 2000. Communicating Globally: An Integrated Marketing Approach. Macmillan Business, London.

Shawchuck N, Kotler P, Wrenn B, Rath G. 1992. Marketing for Congregations. Abingdon Press, Nashville.

Shoham A, Ruvio A, Vigoda-Gadot E, Schwabsky N. 2006. Market Orientations in the nonprofit and voluntary sector: A meta-analysis of their relationships with organizational performance. Nonprofit and Voluntary Sector Quarterly 35(3): 453-467.

Stark R, Iannaccone LR, Finke R. 1996. Religion, science, and rationality. American Economic Review 86(2): 433-437.

Stark R, Finke R. 2000. Acts of Faith: Explaining the Human Side of Religion. Berkeley: University of California Press.

Steenkamp J-B, Gielens K. 2003. Consumer and Market Drivers of the Trial Probability of New Consumer Packaged Goods. Journal of Consumer Research 29 (December): 368-384.

Trevino L, Lengel R, Bodensteiner W, Gerloff E, Muir N. 1990. The richness imperative and cognitive style: The role of individual differences in media choice behavior. Management Communication Quarterly 4(2): 176-197.

Vokurka R, McDaniel S, Cooper N. 2002. Church Marketing Communication Methods: The Effect of Location and Impact on Growth. Services Marketing Quarterly 24(1): 17-32.

Vokurka RJ, McDaniel SW. 2004. A Taxonomy of Church Marketing Strategy Types. Review of Religious Research. 46 (2): 132-149. 
Weber M. 1904. Die protestantische Ethik und der Geist des Kapitalismus/The Protestant Ethic and the Spirit of Capitalism (translated by Talcott Parsons). Routledge, London.

Weimann G, Brosius H-B. 1994. Is there a two-step flow of Agenda Setting? International Journal of Public Opinion 6 (4): 323-341.

Weimann G, Tustin DH, Vuuren D Van, Joubert JPR. 2007. Looking for Opinion Leaders: Traditional vs. Modern Measures in Traditional Societies. International Journal of Public Opinion 19 (2): 173-190.

White DW, Simas CF. 2008. An empirical investigation of the link between market orientation and church performance. International Journal of Nonprofit and Voluntary Sector Marketing 13: 153-165.

Zufryden, FS. 1973. Media Scheduling: A Stochastic Dynamic Model Approach. Management Science 19 (12): 1395-1406.

Zufryden FS. 2000. Predicting Trial, Repeat, and Sales Response from Alternative Media Plans. Journal of the Market Research Society. 40(6): 139-166. 
Table 1: Distribution of the Sample across Religions and Regions, All-India

\begin{tabular}{lcc}
\hline Category & Frequency & Percentage \\
\hline Religion & 272 & \\
Hindu & 248 & 47.89 \\
Muslim & 25 & 43.66 \\
Christian & 23 & 4.40 \\
Other religions & $\mathbf{5 6 8}$ & 4.05 \\
Total & & $\mathbf{1 0 0}$ \\
\hline State & 88 & \\
Gujarat & 82 & 15.49 \\
Jammu and Kashmir & 75 & 14.44 \\
Karnataka & 78 & 13.20 \\
Maharashtra & 75 & 13.73 \\
Madhya Pradesh & 92 & 13.20 \\
Uttar Pradesh & 78 & 16.20 \\
West Bengal & $\mathbf{5 6 8}$ & 13.73 \\
Total & & $\mathbf{1 0 0}$ \\
\hline
\end{tabular}


Table 2: Summary of Religion Survey Research, All-India

\begin{tabular}{|c|c|c|c|}
\hline Name of State & $\begin{array}{c}\text { Number of } \\
\text { Investigators }\end{array}$ & $\begin{array}{c}\text { Average } \\
\text { Number } \\
\text { of Visits } \\
\text { per } \\
\text { Interview }\end{array}$ & Districts of India covered \\
\hline Maharashtra & 4 & 2.4 & Nashik, Mumbai \\
\hline Karnataka & 4 & 2.2 & Bangalore, Belgaum \\
\hline $\begin{array}{l}\text { Madhya } \\
\text { Pradesh }\end{array}$ & 3 & 1.8 & Bhopal, Gwalior, Indore \\
\hline $\begin{array}{l}\text { Jammu and } \\
\text { Kashmir }\end{array}$ & 13 & 2.1 & $\begin{array}{l}\text { Jammu, Udhampur, Srinagar, Pulwama, } \\
\text { Awantipur, Barmulla, Kupwara, Budgam }\end{array}$ \\
\hline Uttar Pradesh & 13 & 3.5 & $\begin{array}{l}\text { Muradabad, Rampur, Bareilly, Allahabad, } \\
\text { Balian, Varansi, Devaria, Ghazipur }\end{array}$ \\
\hline West Bengal & 8 & 2.2 & Kolkata, Burdawan, Howrah \\
\hline Gujarat & 5 & 1.6 & $\begin{array}{l}\text { Surat, Baroda, Junagadh, Amreli, Rajkot, } \\
\text { Ahmedabad }\end{array}$ \\
\hline Total & 50 & & 32 \\
\hline Average & & 2.4 & \\
\hline
\end{tabular}


Table 3: Communication of Information through Different Sources, by Religion

\begin{tabular}{lcccccccccc}
\hline $\begin{array}{l}\text { Communication } \\
\text { Channels }\end{array}$ & \multicolumn{2}{c}{ Hindu } & \multicolumn{2}{c}{ Muslim } & \multicolumn{2}{c}{ Christian } & \multicolumn{2}{c}{ Other } & \multicolumn{2}{c}{ Total } \\
\hline & No. & $\mathbf{\%}$ & No. & $\mathbf{\%}$ & No. & $\mathbf{\%}$ & No. & \% & No. & \% \\
& 46 & 18.5 & 43 & 18.6 & 1 & 4.3 & 6 & 27.3 & 96 & 18.3 \\
$\begin{array}{l}\text { Television/ Radio } \\
\text { Newspapers/Other }\end{array}$ & 183 & 73.5 & 172 & 74.5 & 16 & 69.6 & 15 & 68.2 & 386 & 73.5 \\
$\begin{array}{l}\text { News Media } \\
\text { Local Panchayat }\end{array}$ & 127 & 51.0 & 109 & 47.2 & 16 & 69.6 & 9 & 40.9 & 261 & 49.7 \\
$\begin{array}{l}\text { Meetings } \\
\text { Word of Mouth }\end{array}$ & 185 & 74.3 & 176 & 76.2 & 20 & 87.0 & 13 & 59.1 & 394 & 75.0 \\
$\begin{array}{l}\text { Other - Please } \\
\text { Specify }\end{array}$ & 52 & 20.9 & 40 & 17.3 & 4 & 17.4 & 9 & 40.9 & 105 & 20.0 \\
\hline
\end{tabular}


Table 4: Information about Other Organizations, by Religion

\begin{tabular}{|c|c|c|c|c|c|c|c|c|c|c|}
\hline \multirow{2}{*}{$\begin{array}{l}\text { Communication } \\
\text { Channels }\end{array}$} & \multicolumn{2}{|c|}{ Hindu } & \multicolumn{2}{|c|}{ Muslim } & \multicolumn{2}{|c|}{ Christian } & \multicolumn{2}{|c|}{ Other } & \multicolumn{2}{|c|}{ Total } \\
\hline & No. & $\%$ & No. & $\%$ & No. & $\%$ & No. & $\%$ & No. & $\%$ \\
\hline Television/Radio & 33 & 14.4 & 64 & 26.7 & 6 & 26.1 & 3 & 13.0 & 106 & 20.6 \\
\hline $\begin{array}{l}\text { Newspapers/Other } \\
\text { News Media }\end{array}$ & 185 & 80.8 & 196 & 81.7 & 21 & 91.3 & 14 & 60.9 & 416 & 80.8 \\
\hline $\begin{array}{l}\text { Local Panchayat } \\
\text { Meetings }\end{array}$ & 107 & 46.7 & 83 & 34.6 & 6 & 26.1 & 18 & 78.3 & 214 & 41.6 \\
\hline Word of Mouth & 195 & 85.2 & 183 & 76.3 & 15 & 65.2 & 19 & 82.6 & 412 & 80.0 \\
\hline $\begin{array}{l}\text { Other - Please } \\
\text { Specify }\end{array}$ & 14 & 6.1 & 30 & 12.5 & 4 & 17.4 & 0 & 0.0 & 48 & 9.3 \\
\hline
\end{tabular}


Table 5: Variable Definitions and Summary Statistics

\begin{tabular}{|c|c|c|c|c|}
\hline Variable & Name & Definition & Mean & $\begin{array}{l}\text { Standard } \\
\text { deviation }\end{array}$ \\
\hline \multicolumn{5}{|c|}{ Dependent Variables } \\
\hline $\begin{array}{l}\text { No. of direct } \\
\text { channels used }\end{array}$ & Direct channels & $\begin{array}{l}\text { Total no. of indirect channels } \\
\text { (local Panchayat meetings, } \\
\text { word-of-mouth and others) } \\
\text { used }\end{array}$ & 1.66 & 0.71 \\
\hline $\begin{array}{l}\text { No. of indirect } \\
\text { channels used }\end{array}$ & Indirect channels & $\begin{array}{l}\text { Total no. of direct channels } \\
\text { (TV, Newspaper and other } \\
\text { print media) used }\end{array}$ & 1.15 & 0.66 \\
\hline \multicolumn{5}{|c|}{ Control Variables: Fixed Effects } \\
\hline Region & Region & $\begin{array}{l}\text { Equals } 1 \text { for stated region } \\
\text { (Jammu \& Kashmir, Uttar } \\
\text { Pradesh, Karnataka, Gujarat, } \\
\text { Uttar Pradesh, West Bengal); } \\
\text { base group Madhya Pradesh }\end{array}$ & - & - \\
\hline Religion & Religion & $\begin{array}{l}\text { Equals } 1 \text { for stated religion } \\
\text { (Christian, Muslim, Others); } \\
\text { base group Hindu }\end{array}$ & - & - \\
\hline \multicolumn{5}{|c|}{ Control Variables: Organizational Factors } \\
\hline $\begin{array}{l}\text { Total no. of } \\
\text { adherents }\end{array}$ & Adherents & Total no. of adherents in 2007 & $\begin{array}{c}11.26 \mathrm{x} \\
10^{4}\end{array}$ & $\begin{array}{c}15.88 \mathrm{x} \\
10^{4}\end{array}$ \\
\hline $\begin{array}{l}\text { Magnitude of } \\
\text { religious gatherings }\end{array}$ & Gatherings & $\begin{array}{l}\text { Summation of no. of } \\
\text { adherents in four major } \\
\text { religious festivals }\end{array}$ & $\begin{array}{c}85.89 x \\
10^{3}\end{array}$ & $\begin{array}{l}21.03 \mathrm{x} \\
10^{4}\end{array}$ \\
\hline $\begin{array}{l}\text { Operation in multiple } \\
\text { districts }\end{array}$ & Multiple districts & $\begin{array}{l}\text { Equals } 1 \text { if organization } \\
\text { operates in multiple districts }\end{array}$ & 0.76 & 0.42 \\
\hline Location & Location & $\begin{array}{l}\text { operates in Rural location; } \\
\text { base group Urban }\end{array}$ & 0.07 & 0.26 \\
\hline \multicolumn{5}{|c|}{ Explanatory Variables: Competitive Factors } \\
\hline $\begin{array}{l}\text { No. of direct } \\
\text { channels used by } \\
\text { competitor }\end{array}$ & $\begin{array}{l}\text { Competitor direct } \\
\text { channels }\end{array}$ & $\begin{array}{l}\text { Total no. of direct channels } \\
\text { through which the incumbent } \\
\text { religious organization } \\
\text { receives information about its } \\
\text { competitors }\end{array}$ & 1.81 & 0.74 \\
\hline $\begin{array}{l}\text { No. of indirect } \\
\text { channels used by } \\
\text { competitor }\end{array}$ & $\begin{array}{l}\text { Competitor indirect } \\
\text { channels }\end{array}$ & $\begin{array}{l}\text { Total no. of indirect channels } \\
\text { through which the incumbent } \\
\text { religious organization } \\
\text { receives information about its }\end{array}$ & 1.08 & 0.65 \\
\hline
\end{tabular}


Degree of responsiveness towards religious service

Degree of responsiveness towards nonreligious service Competitive advantage in religious services Competitive advantage in nonreligious services

No. of larger competitors
Responsiveness

religious

Responsiveness nonreligious

Advantage religious

Advantage nonreligious

Larger competitors

\section{competitors}

Equals 1 if organization has provided a new religious service in response to

competition

Equals 1 if organization has

provided a new non-religious

service in response to

0.18

competition

Difference in terms of $\begin{array}{lll}\text { provision of religious services } & 0.47 & 0.68\end{array}$ across religions

Difference in terms of $\begin{array}{lll}\text { provision of non-religious } & 0.38 & 0.59\end{array}$ services across religions No. of competitors that are larger than the incumbent religious organization

\section{Explanatory Variables: Change in Service Factors}

Change in religious services

Change religious

Change in nonreligious services
Equates 1 if religious services provided now are more/less traditional in comparison to 20 years back Equates 1 if provision of education and health services have changed over the period

0.58 1990-2006

\begin{tabular}{|c|c|c|c|c|}
\hline \multicolumn{5}{|c|}{ Explanatory Variables: Message Factors } \\
\hline $\begin{array}{l}\text { No. of religious } \\
\text { services provided }\end{array}$ & $\begin{array}{l}\text { Number of religious } \\
\text { services }\end{array}$ & $\begin{array}{l}\text { Total no. of different } \\
\text { religious services that the } \\
\text { organization provides }\end{array}$ & 0.76 & 0.81 \\
\hline $\begin{array}{l}\text { No. of non-religious } \\
\text { services provided }\end{array}$ & $\begin{array}{l}\text { Number of non- } \\
\text { religious services }\end{array}$ & $\begin{array}{l}\text { Total no. of different non- } \\
\text { religious services that the } \\
\text { organization provides post- } \\
1991\end{array}$ & 1.99 & 1.34 \\
\hline
\end{tabular}


Table 6: Direct Communication Channels: Frequency Distribution

\begin{tabular}{lccc}
\hline \hline $\begin{array}{l}\text { Number of Direct Communication } \\
\text { Channels used }\end{array}$ & Count & Frequency & $\begin{array}{c}\text { Cumulative } \\
\text { Frequency }\end{array}$ \\
\hline 0 & 12 & 2.11 & 2.11 \\
1 & 237 & 41.73 & 43.84 \\
2 & 250 & 44.01 & 87.85 \\
3 & 69 & 12.15 & 100.00 \\
\hline
\end{tabular}

Table 7: Indirect Communication Channels: Frequency Distribution

\begin{tabular}{lccc}
\hline \hline $\begin{array}{l}\text { Number of Indirect Communication } \\
\text { Channels used }\end{array}$ & Count & Frequency & $\begin{array}{c}\text { Cumulative } \\
\text { Frequency }\end{array}$ \\
\hline 0 & 90 & 15.85 & 15.85 \\
1 & 302 & 53.17 & 69.01 \\
2 & 176 & 30.99 & 100.00 \\
\hline
\end{tabular}


Table 8: Estimation for Indirect Communication Channels

\begin{tabular}{|c|c|c|c|c|c|}
\hline Variable & $\begin{array}{c}\text { (1) } \\
\text { Fixed effects }\end{array}$ & $\begin{array}{c}\text { (2) } \\
\text { With } \\
\begin{array}{c}\text { Organizational } \\
\text { factors }\end{array}\end{array}$ & $\begin{array}{c}\text { (3) } \\
\text { With } \\
\text { Change } \\
\text { Factors }\end{array}$ & $\begin{array}{c}\text { (4) } \\
\text { With } \\
\text { Message } \\
\text { factors }\end{array}$ & $\begin{array}{c}\text { (5) } \\
\text { With } \\
\text { Competition } \\
\text { factors }\end{array}$ \\
\hline Christian & $\begin{array}{c}0.126 \\
(0.098)\end{array}$ & $\begin{array}{c}0.064 \\
(0.098)\end{array}$ & $\begin{array}{c}0.065 \\
(0.100)\end{array}$ & $\begin{array}{c}0.078 \\
(0.107)\end{array}$ & $\begin{array}{c}0.111 \\
(0.108)\end{array}$ \\
\hline Muslim & $\begin{array}{c}-0.004 \\
(0.063)\end{array}$ & $\begin{array}{l}-0.016 \\
(0.056)\end{array}$ & $\begin{array}{l}-0.015 \\
(0.062)\end{array}$ & $\begin{array}{l}-0.006 \\
(0.055)\end{array}$ & $\begin{array}{c}0.034 \\
(0.055)\end{array}$ \\
\hline Other religions & $\begin{array}{c}0.016 \\
(0.149)\end{array}$ & $\begin{array}{c}0.004 \\
(0.170)\end{array}$ & $\begin{array}{l}0.005 \\
(0.214)\end{array}$ & $\begin{array}{c}-0.002 \\
(0.166)\end{array}$ & $\begin{array}{l}-0.037 \\
(0.176)\end{array}$ \\
\hline Jammu and Kashmir & $\begin{array}{c}0.147 \\
(0.152)\end{array}$ & $\begin{array}{c}0.113 \\
(0.146)\end{array}$ & $\begin{array}{l}0.113 \\
(0.155)\end{array}$ & $\begin{array}{c}0.077 \\
(0.147)\end{array}$ & $\begin{array}{c}0.083 \\
(0.133)\end{array}$ \\
\hline Karnataka & $\begin{array}{l}0.383^{*} \\
(0.107)\end{array}$ & $\begin{array}{l}0.366^{*} \\
(0.123)\end{array}$ & $\begin{array}{l}0.366^{*} \\
(0.135)\end{array}$ & $\begin{array}{l}0.364 * \\
(0.133)\end{array}$ & $\begin{array}{l}0.273^{*} \\
(0.114)\end{array}$ \\
\hline Maharashtra & $\begin{array}{l}0.499 * \\
(0.104)\end{array}$ & $\begin{array}{l}0.518^{*} \\
(0.128)\end{array}$ & $\begin{array}{l}0.517^{*} \\
(0.128)\end{array}$ & $\begin{array}{l}0.519 * \\
(0.120)\end{array}$ & $\begin{array}{l}0.385^{*} \\
(0.112)\end{array}$ \\
\hline Gujarat & $\begin{array}{l}0.347^{*} \\
(0.116)\end{array}$ & $\begin{array}{l}0.324^{*} \\
(0.130)\end{array}$ & $\begin{array}{l}0.319^{*} \\
(0.148)\end{array}$ & $\begin{array}{l}0.315^{*} \\
(0.136)\end{array}$ & $\begin{array}{l}0.244^{*} \\
(0.118)\end{array}$ \\
\hline Uttar Pradesh & $\begin{array}{l}0.547 * \\
(0.096)\end{array}$ & $\begin{array}{l}0.511 * \\
(0.115)\end{array}$ & $\begin{array}{l}0.509 * \\
(0.131)\end{array}$ & $\begin{array}{l}0.458^{*} \\
(0.113)\end{array}$ & $\begin{array}{l}0.352^{*} \\
(0.117)\end{array}$ \\
\hline West Bengal & $\begin{array}{l}0.568^{*} \\
(0.099)\end{array}$ & $\begin{array}{l}0.541^{*} \\
(0.116)\end{array}$ & $\begin{array}{l}0.539 * \\
(0.131)\end{array}$ & $\begin{array}{l}0.511^{*} \\
(0.096)\end{array}$ & $\begin{array}{l}0.463^{*} \\
(0.114)\end{array}$ \\
\hline Adherents & & $\begin{array}{l}-0.000 \\
(0.000)\end{array}$ & $\begin{array}{l}-0.000 \\
(0.000)\end{array}$ & $\begin{array}{l}-0.000 \\
(0.000)\end{array}$ & $\begin{array}{l}-0.000 \\
(0.000)\end{array}$ \\
\hline Gatherings & & $\begin{array}{l}-0.000 \\
(0.000)\end{array}$ & $\begin{array}{l}-0.000 \\
(0.000)\end{array}$ & $\begin{array}{l}-0.000 \\
(0.000)\end{array}$ & $\begin{array}{l}-0.000 \\
(0.000)\end{array}$ \\
\hline Multiple districts & & $\begin{array}{c}0.078 \\
(0.060)\end{array}$ & $\begin{array}{l}0.079 \\
(0.065)\end{array}$ & $\begin{array}{c}0.083 \\
(0.046)\end{array}$ & $\begin{array}{c}0.096 \\
(0.055)\end{array}$ \\
\hline Location & & $\begin{array}{c}0.076 \\
(0.072)\end{array}$ & $\begin{array}{l}0.077 \\
(0.071)\end{array}$ & $\begin{array}{c}0.059 \\
(0.079)\end{array}$ & $\begin{array}{c}0.089 \\
(0.079)\end{array}$ \\
\hline Service change religious & & & $\begin{array}{l}-0.007 \\
(0.050)\end{array}$ & $\begin{array}{l}-0.012 \\
(0.062)\end{array}$ & $\begin{array}{l}-0.016 \\
(0.053)\end{array}$ \\
\hline Service change non-religious & & & $\begin{array}{l}-0.008 \\
(0.046)\end{array}$ & $\begin{array}{l}-0.025 \\
(0.052)\end{array}$ & $\begin{array}{c}0.012 \\
(0.047)\end{array}$ \\
\hline $\begin{array}{l}\text { Number of religious } \\
\text { services*Responsiveness } \\
\text { religious }\end{array}$ & & & & $\begin{array}{c}0.019 \\
(0.094)\end{array}$ & $\begin{array}{c}0.024 \\
(0.099)\end{array}$ \\
\hline
\end{tabular}


Number of non-religious

0.047* 0.054 *

services*Responsiveness non-

Competitor direct channels

Competitor indirect channels

Competitor direct channels

Competitor direct channels

*Larger competitors

Competitor indirect channels

Interaction 1

Interaction 2

Interaction 3

\begin{tabular}{|c|c|c|c|c|c|}
\hline \multicolumn{6}{|c|}{ Goodness-of-fit } \\
\hline $\begin{array}{l}\text { Likelihood Ratio Test } \\
\text { (full model) }\end{array}$ & $\begin{array}{l}23.084 \\
(0.006)\end{array}$ & $\begin{array}{l}23.602 \\
(0.035)\end{array}$ & $\begin{array}{l}23.619 \\
(0.072)\end{array}$ & $\begin{array}{l}25.020 \\
(0.094)\end{array}$ & $\begin{array}{l}32.505 \\
(0.144)\end{array}$ \\
\hline $\begin{array}{l}\text { Bayesian Information } \\
\text { Criterion }\end{array}$ & -2194.410 & -1978.560 & -1966.038 & -1954.901 & -1912.234 \\
\hline \multicolumn{6}{|c|}{$\begin{array}{l}\text { * denotes significance at } 10 \% \text { level of significance. Standard errors reported in parentheses and are calculated using the } \\
\text { bootstrap method. Negative binomial estimates (not reported, available upon request) do not differ noticeably. Coefficient } \\
\text { estimates reported in terms of percentage change in dependent count. Interaction 1: Competitor direct channels*Responsiveness } \\
\text { religious*Advantage religious, Interaction 2: Competitor direct channels*Responsiveness non-religious*Advantage non- } \\
\text { religious, Interaction 3: Competitor indirect channels*Responsiveness religious*Advantage religious, Interaction 4: Competitor } \\
\text { indirect channels*Responsiveness non-religious*Advantage non-religious. }\end{array}$} \\
\hline
\end{tabular}


Table 9: Estimation for Direct Communication Channels

\begin{tabular}{|c|c|c|c|c|c|}
\hline Variable & $\begin{array}{c}\text { (1) } \\
\text { Fixed effects }\end{array}$ & $\begin{array}{c}(2) \\
\text { With } \\
\text { Organizational } \\
\text { factors }\end{array}$ & $\begin{array}{c}\text { (3) } \\
\text { With } \\
\text { Change } \\
\text { Factors }\end{array}$ & $\begin{array}{c}\text { (4) } \\
\text { With } \\
\text { Message } \\
\text { factors }\end{array}$ & $\begin{array}{c}\text { (5) } \\
\text { With } \\
\text { Competition } \\
\text { factors }\end{array}$ \\
\hline Christian & $\begin{array}{l}-0.074 \\
(0.094)\end{array}$ & $\begin{array}{l}-0.107 \\
(0.103)\end{array}$ & $\begin{array}{c}-0.119 \\
(0.092)\end{array}$ & $\begin{array}{c}-0.130 \\
(0.097)\end{array}$ & $\begin{array}{c}-0.138 \\
(0.092)\end{array}$ \\
\hline Muslim & $\begin{array}{c}0.115^{*} \\
(0.033)\end{array}$ & $\begin{array}{l}0.125^{*} \\
(0.043)\end{array}$ & $\begin{array}{l}0.123^{*} \\
(0.038)\end{array}$ & $\begin{array}{l}0.116^{*} \\
(0.040)\end{array}$ & $\begin{array}{l}0.097 * \\
(0.044)\end{array}$ \\
\hline Other religions & $\begin{array}{c}0.040 \\
(0.131)\end{array}$ & $\begin{array}{c}0.056 \\
(0.139)\end{array}$ & $\begin{array}{c}0.049 \\
(0.121)\end{array}$ & $\begin{array}{c}0.056 \\
(0.118)\end{array}$ & $\begin{array}{c}0.092 \\
(0.126)\end{array}$ \\
\hline Jammu and Kashmir & $\begin{array}{c}-0.051 \\
(0.067)\end{array}$ & $\begin{array}{l}-0.085 \\
(0.067)\end{array}$ & $\begin{array}{l}-0.088 \\
(0.074)\end{array}$ & $\begin{array}{l}-0.052 \\
(0.063)\end{array}$ & $\begin{array}{l}-0.081 \\
(0.066)\end{array}$ \\
\hline Karnataka & $\begin{array}{l}-0.143^{*} \\
(0.052)\end{array}$ & $\begin{array}{l}-0.201^{*} \\
(0.068)\end{array}$ & $\begin{array}{l}-0.219^{*} \\
(0.080)\end{array}$ & $\begin{array}{l}-0.217^{*} \\
(0.076)\end{array}$ & $\begin{array}{l}-0.184^{*} \\
(0.073)\end{array}$ \\
\hline Maharashtra & $\begin{array}{l}0.232 * \\
(0.051)\end{array}$ & $\begin{array}{l}0.192^{*} \\
(0.068)\end{array}$ & $\begin{array}{c}0.179 * \\
(0.065)\end{array}$ & $\begin{array}{l}0.179 * \\
(0.070)\end{array}$ & $\begin{array}{l}0.186^{*} \\
(0.085)\end{array}$ \\
\hline Gujarat & $\begin{array}{l}-0.035 \\
(0.066)\end{array}$ & $\begin{array}{l}-0.102 \\
(0.065)\end{array}$ & $\begin{array}{l}-0.103 \\
(0.066)\end{array}$ & $\begin{array}{l}-0.099 \\
(0.078)\end{array}$ & $\begin{array}{l}-0.078 \\
(0.065)\end{array}$ \\
\hline Uttar Pradesh & $\begin{array}{l}-0.284 * \\
(0.046)\end{array}$ & $\begin{array}{l}-0.300^{*} \\
(0.063)\end{array}$ & $\begin{array}{c}-0.299 * \\
(0.073)\end{array}$ & $\begin{array}{c}-0.253^{*} \\
(0.075)\end{array}$ & $\begin{array}{l}-0.199 * \\
(0.073)\end{array}$ \\
\hline West Bengal & $\begin{array}{l}-0.177^{*} \\
(0.057)\end{array}$ & $\begin{array}{l}-0.182^{*} \\
(0.070)\end{array}$ & $\begin{array}{l}-0.183^{*} \\
(0.067)\end{array}$ & $\begin{array}{l}-0.158^{*} \\
(0.070)\end{array}$ & $\begin{array}{l}-0.141^{*} \\
(0.072)\end{array}$ \\
\hline Adherents & & $\begin{array}{l}-0.000 \\
(0.000)\end{array}$ & $\begin{array}{l}-0.000 \\
(0.000)\end{array}$ & $\begin{array}{l}-0.000 \\
(0.000)\end{array}$ & $\begin{array}{l}-0.000 \\
(0.000)\end{array}$ \\
\hline Gatherings & & $\begin{array}{l}-0.000 \\
(0.000)\end{array}$ & $\begin{array}{c}-0.000 \\
(0.000)\end{array}$ & $\begin{array}{l}-0.000 \\
(0.000)\end{array}$ & $\begin{array}{c}-0.000 \\
(0.000)\end{array}$ \\
\hline Multiple districts & & $\begin{array}{c}0.052 \\
(0.038)\end{array}$ & $\begin{array}{c}0.045 \\
(0.043)\end{array}$ & $\begin{array}{c}0.042 \\
(0.043)\end{array}$ & $\begin{array}{c}0.034 \\
(0.043)\end{array}$ \\
\hline Location & & $\begin{array}{c}0.025 \\
(0.066)\end{array}$ & $\begin{array}{c}0.026 \\
(0.069)\end{array}$ & $\begin{array}{c}0.038 \\
(0.066)\end{array}$ & $\begin{array}{c}0.030 \\
(0.077)\end{array}$ \\
\hline Service change religious & & & $\begin{array}{c}-0.028 \\
(0.043)\end{array}$ & $\begin{array}{l}-0.024 \\
(0.049)\end{array}$ & $\begin{array}{c}-0.032 \\
(0.040)\end{array}$ \\
\hline Service change non-religious & & & $\begin{array}{l}0.066^{*} \\
(0.035)\end{array}$ & $\begin{array}{l}0.079 * \\
(0.038)\end{array}$ & $\begin{array}{l}0.055^{*} \\
(0.041)\end{array}$ \\
\hline
\end{tabular}




\begin{tabular}{|c|c|c|c|c|c|}
\hline \multirow{2}{*}{$\begin{array}{l}\text { Number of religious } \\
\text { services*Responsiveness } \\
\text { religious } \\
\text { Number of non-religious } \\
\text { services*Responsiveness non- } \\
\text { religious }\end{array}$} & & & & $\begin{array}{l}-0.037 \\
(0.063)\end{array}$ & $\begin{array}{l}-0.048 \\
(0.056)\end{array}$ \\
\hline & & & & $\begin{array}{l}-0.045^{*} \\
(0.022)\end{array}$ & $\begin{array}{l}-0.025^{*} \\
(0.027)\end{array}$ \\
\hline \multicolumn{3}{|l|}{ Competitor direct channels } & & & $\begin{array}{c}0.035 \\
(0.028)\end{array}$ \\
\hline \multicolumn{3}{|l|}{ Competitor indirect channels } & & & $\begin{array}{l}-0.047 \\
(0.036)\end{array}$ \\
\hline \multicolumn{3}{|l|}{$\begin{array}{l}\text { Competitor direct channels } \\
\text { *Larger competitors }\end{array}$} & & & $\begin{array}{l}0.015^{*} \\
(0.009)\end{array}$ \\
\hline \multicolumn{3}{|l|}{$\begin{array}{l}\text { Competitor indirect channels } \\
\text { *Larger competitors }\end{array}$} & & & $\begin{array}{l}-0.015 \\
(0.015)\end{array}$ \\
\hline \multicolumn{3}{|l|}{ Interaction 1} & & & $\begin{array}{c}0.043 \\
(0.067)\end{array}$ \\
\hline \multicolumn{3}{|l|}{ Interaction 2} & & & $\begin{array}{l}-0.112 \\
(0.116)\end{array}$ \\
\hline \multicolumn{3}{|l|}{ Interaction 3} & & & $\begin{array}{c}0.031 \\
(0.105)\end{array}$ \\
\hline \multicolumn{3}{|l|}{ Interaction 4} & & & $\begin{array}{c}0.078 \\
(0.112)\end{array}$ \\
\hline \multicolumn{6}{|c|}{ Goodness-of-fit } \\
\hline $\begin{array}{l}\text { Likelihood Ratio Test } \\
\text { (full model) }\end{array}$ & $\begin{array}{l}22.034 \\
(0.009)\end{array}$ & $\begin{array}{l}23.024 \\
(0.041)\end{array}$ & $\begin{array}{l}23.897 \\
(0.067)\end{array}$ & $\begin{array}{l}25.418 \\
(0.086)\end{array}$ & $\begin{array}{l}28.768 \\
(0.274)\end{array}$ \\
\hline $\begin{array}{l}\text { Bayesian Information } \\
\text { Criterion }\end{array}$ & -2038.21 & -1834.12 & -1822.45 & -1811.43 & -1764.63 \\
\hline \multicolumn{6}{|c|}{$\begin{array}{l}\text { * denotes significance at } 10 \% \text { level of significance. Standard errors reported in parentheses and are calculated using the } \\
\text { bootstrap method. Negative binomial estimates (not reported, available upon request) do not differ noticeably. Coefficient } \\
\text { estimates reported in terms of percentage change in dependent count. Interaction 1: Competitor direct channels*Responsiveness } \\
\text { religious*Advantage religious, Interaction 2: Competitor direct channels*Responsiveness non-religious*Advantage non- } \\
\text { religious, Interaction 3: Competitor indirect channels*Responsiveness religious*Advantage religious, Interaction 4: Competitor } \\
\text { indirect channels*Responsiveness non-religious*Advantage non-religious. }\end{array}$} \\
\hline
\end{tabular}

